\title{
Action of the Tamsulosin in Permeability of Airways at Patients with Increased Bronchial Reactibility
}

\author{
Hilmi Islami ${ }^{1 *}$, Milaim Abdullahu ${ }^{2}$, Ali Ilazi ${ }^{3}$, Naim Morina ${ }^{4}$, Feim Haliti ${ }^{5}$, Aziz Sukalo ${ }^{6}$, Arlinda Lekaj ${ }^{4}$ and Bashkim Kastrati ${ }^{4}$
}

${ }^{1}$ Department of Pharmacology, Faculty of Medicine, University of Prishtina, Clinical Centre, Mother Theresa Str., 10000, Prishtina, Kosova

${ }^{2}$ Santefarm Ltd, Prishtina, Kosova

${ }^{3}$ Kosovo Occupationnal Health Institute, Clinical Centre N.N. 10000, Gjakova, Kosova

${ }^{4}$ Department of Pharmacy, Faculty of Medicine, University of Prishtina, Clinical Centre, Mother Theresa Str., 10000, Prishtina, Kosova

${ }^{5}$ Department of Stom., Faculty of Medicine, University of Prishtina, Clinical Centre, Mother Theresa Str., 10000, Prishtina, Kosova

${ }^{6}$ Drags factory "Bosnalijek" - Sarajevo, Bosnalijek dd, Jukiceva 53, 71000 Sarajevo, Bosna

\begin{abstract}
In this work, effect of Tamsulosin hydrochloride as antagonist of alpha1A and alpha1B- adrenergic receptor in patients with bronchial hyper-reactibility was studied

Parameters of the lung function are determined by Body plethysmography. Raw and ITGV were registered and specific resistance (SRaw) was also calculated. Tamsulosin was administered in per os way as a preparation in the form of the capsules with a brand name of "Prolosin", producer: Niche Generics Limited, Hitchin, Herts SG4 OTW, United Kingdom.

Results gained by this research shows that blockage of alpha1A and alpha1B- adrenergic receptor with Tamsulosin hydrochloride $(0.4 \mathrm{mg}$ in per os way) has not changed significantly $(p>0.1)$ the bronchomotor tonus of tracheobronchial tree in comparison to the inhalation of Salbutamol $(2 \mathrm{inh} . \times 0.2 \mathrm{mg}),(\mathrm{p}<0.01)$

This suggests that the activity of alpha1A and alpha1B- adrenergic receptor in the smooth musculature is not a primary mechanism which causes reaction in patients with increased bronchial reactibility, in comparison to agonists of beta2 - adrenergic receptor which emphasizes their significant action in the reduction of specific resistance of airways.
\end{abstract}

Keywords: Tamsulosin hydrochloride; Salbutamol

\section{Introduction}

Importance of autonomic nervous system, in the bronchomotor tonus of the airways is researched intensively last years. Particular care is paid to the adrenergic and cholinergic impacts. Importance of adrenergic action in the regulation of bronchomotor tonus is not quiet known. They can act through beta $_{2}$ or alpha ${ }_{1}$ - adrenergic receptor in the smooth musculature of airways and modify their permeability [1].

Gilbert et al. [2] consider that alpha ${ }_{1}$ adrenergic receptors in the smooth bronchial musculature may be stimulated only with a direct action of catecholamine in circulation, and only in physiologic doses because that very rare sympathetic innervations lies on bronchial tree.

Researches "in vivo" in experimental animals and in isolated segments of human bronchi has proved the presence of a small number of alpha-adrenergic receptor. These researches have also proved that the presence of this receptor in pulmonary diseases is increased by suggesting the role of this receptor in the patho-physiologic mechanism of bronchial asthma [3]. Up to date, some aspects of patho-physiology, diagnoses, treatment and prophylaxis in asthma have remained yet unclear [4].

Increased bronchial irritability of airways in asthmatics is caused also by the autonomic dis-balance, which derives from the decreased beta-adrenergic function, which results in increase of cholinergic and alpha-adrenergic response to different stimulators [5]. Many researchers potentiate that in the group of selected asthmatic patient, without effects from other medicaments, administration of alphaadrenergic antagonist leads towards improvement of the airways function [6]. Alpha-adrenergic antagonist (e.g. indoramin) causes the bronchodilation due to the blocking of alpha-adrenergic receptor and can be useful therapeutics for a certain asthmatic population [7]. Remains unclear whether these result are caused by the blockage of stimulation of alpha-adrenergic receptor of mastocytes, or airways smooth muscles [8].

Lately, experiments conducted in vivo shows that clonidine intermediates an inhibitory control over the existing activity of vagal excitation [9]. However, these results are not verified by other researchers. Some authors have verified that in the group of asthmatics, agonist of alpha ${ }_{1}$-adrenergic receptor, inhaled phenylephrine does not affect in the airways resistance [10].

In the mechanism of lung obstructive diseases and of bronchial asthma, important role has also modulator substances being released following the inflammatory processes and other substances following the degranulation process of mastocyte [11].

Airways smooth musculature tonus is under the influence of different neurotransmitters, hormones, drugs and mediators which do manifest their action by connecting to the surface of the specific receptor in airways smooth musculature cells. All these factors, related to the tonus of airways musculature, manifest their action by excitatory effect (agonist) and inhibitory effect (antagonist) during the connection to respective receptor localized in airways musculature cells [12].

*Corresponding author: Hilmi Islami, Institute of Clinical Pharmacology and Toxicology, Faculty of Medicine, Prishtina University, Kosova, Tel: 0037745437 415; Fax: 0038138551 001; E-mail: islamihilmi@hotmail.com

Received January 30, 2012; Accepted March 27, 2012; Published March 28, 2012

Citation: Islami H, Abdullahu M, llazi A, Morina N, Haliti F, et al. (2012) Action of the Tamsulosin in Permeability of Airways at Patients with Increased Bronchial Reactibility. Clin Exp Pharmacol 2:106. doi:10.4172/2161-1459.1000106

Copyright: () 2012 Islami $\mathrm{H}$, et al. This is an open-access article distributed under the terms of the Creative Commons Attribution License, which permits unrestricted use, distribution, and reproduction in any medium, provided the original author and source are credited. 
Activation of action of some above mentioned factors can be initiated also by the outside environment factors such are physical activity or exposure to cold air. Actually, it is supposed that during the exposure to cold air, bronchoconstriction can be initiated through the increase of the alpha adrenergic receptor activity. Therefore, this fact has placed in the focus the role of alpha adrenergic receptor in the mechanism of asthma [13].

This work aims the assessment of the importance of alpha-adrenergic system in the regulation of bronchomotor tonus in patients with bronchial hyper-reactibility. Effect of the Tamsulosin hydrochloride as the alpha ${ }_{1 \mathrm{~A}}$ and alpha ${ }_{1 \mathrm{~B}}$ - adrenergic receptor antagonist in patients with increased bronchial hyper-reactibility in comparison to the effect of beta ${ }_{2}$ adrenergic agonists (Salbutamol).

\section{Material and Methods}

This study project was allowed by the Ethic Committee of the Medical Faculty in Prishtina.

Examinations are done in 25 patients (20 females and 5 males), with bronchial reactibility (middle reactor and severe reactor), middle reactor (14) and severe reactor (11). Selection of patients was done based to the anamnestic data and lung clinical and functional researches, which are provided in the Table 1.

Researched were informed regarding the aim of examination. At least 48 hours prior research commence, examined persons has not administered any of the drugs or substances which to affect the results of the examination. Lung function was determined in the silence condition. This determination is composed of the measurement of the slowed vital capacity $(\mathrm{VC})$, forced expiratory volume $\left(\mathrm{FEV}_{1}\right)$ with Godardt Company pneumotest, and afterwards by metering of the resistance of the air flow in lung (Raw) and intratoracal volume of gases (ITGV) with the body plethysmography (Figure 1). From the gained Raw and ITGV results, specific resistance (SRaw) was calculated.

\section{SRaw $=$ Raw $x$ ITGV}

Measurement of parameters of the gas volume in the sternum (ITGV);

registration of curve flux-volume (inspiratory flux and expiratory flux - L/min);

Resistance of airways (Raw - L/sec) expressed in $\mathrm{kPa}$.

In persons with bronchial reactibility (middle reactor and severe reactor) following the measurement of initial values Tamsulosin hydrochloride was applied (alpha $\mathrm{IA}_{\mathrm{A}}$ and $\mathrm{alpha}_{1 \mathrm{~B}}$-adrenergic antagonist) with per os way (0.4 mg-aerosol), and after 60 and $120 \mathrm{~min}$. Raw and ITGV were measured, and afterwards Salbutamol as aerosol was applied in the end (beta ${ }_{2}$-adrenergic agonist) in a dose of ( 2 inh. x $0.2 \mathrm{mg}$ ), Raw and ITGV values were measured again and SRaw was calculated.

Results were processed with a computer statistic program GraphPad InStat III with t-test of comparison of two working groups.

\section{Results}

Results of this research, in patients with bronchial reactibility (middle reactor and severe reactor), shows that blockage of alpha and alpha ${ }_{1 \mathrm{~B}}$-adrenergic receptor with Tamsulosin hydrochloride (0.4 mg with per os way) does not change significantly $(\mathrm{p}>0.1)$ the bronchomotor tonus of the tracheobronchial system, in comparison to Salbutamol (beta ${ }_{2}$-adrenergic agonist) which is very effective in removal of the increased bronchomotor tonus, by causing significant decrease of the resistance (Raw), respectively of specific resistance (SRaw) $(\mathrm{p}<0,01)$. See Figure 2 and 3.

Tamsulosin is a blocker of alpha ${ }_{1 \mathrm{~A}}$ and alpha ${ }_{1 \mathrm{~B}}$-adrenergic receptor which lowers the arterial systolic and diastolic pressure (TA) but not in a significant manner $(\mathrm{p}>0.1)$ (Figure 4$)$.

\begin{tabular}{|l|l|l|l|l|l|l|}
\hline $\mathbf{n}$ & Age $(\mathrm{v})$ & Height $(\mathrm{cm})$ & Mass $(\mathrm{kg})$ & VC $(\%)$ & FEV $(\%)$ & Raw $(\mathrm{kPa} \mathrm{L/s})$ \\
\hline $\mathbf{2 5}$ & $40,4 \pm 5,0$ & $169,7 \pm 2,4$ & $73,8 \pm 2,9$ & $60,8 \pm 20,1$ & $65,2 \pm 11,2$ & $0,41 \pm 0,33$ \\
\hline
\end{tabular}

Table 1: Basic characteristics and pulmonary function in examined.

A)

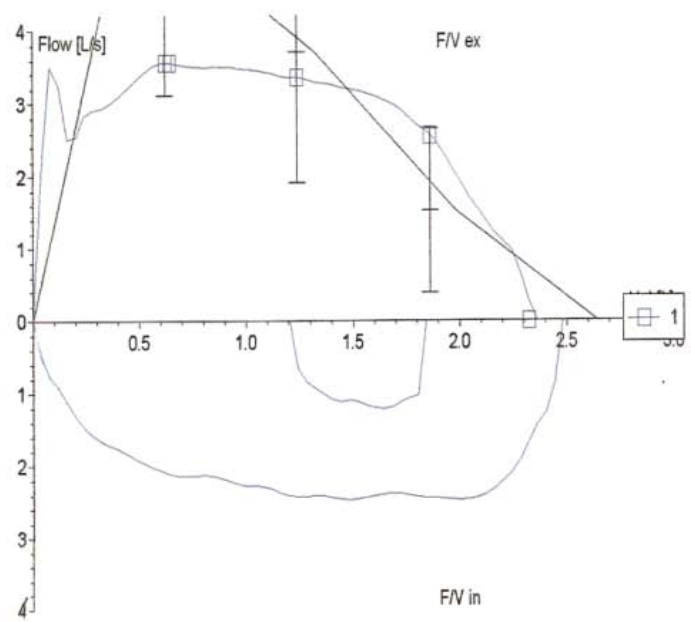

B)

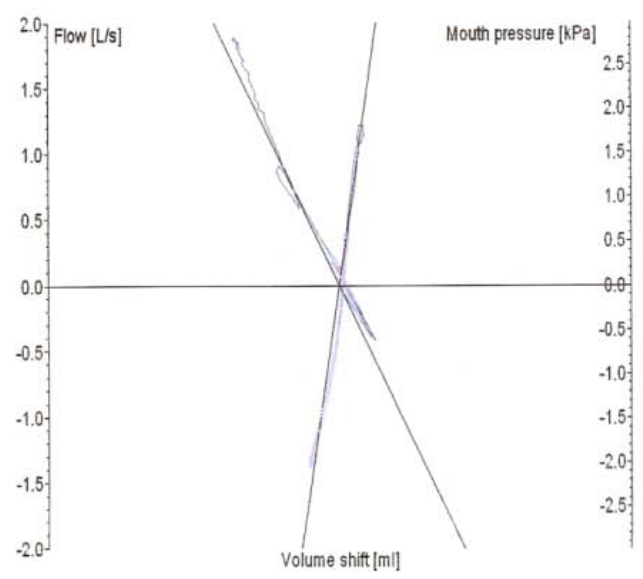

Figure 1: Measurement with Body plethysmography. 


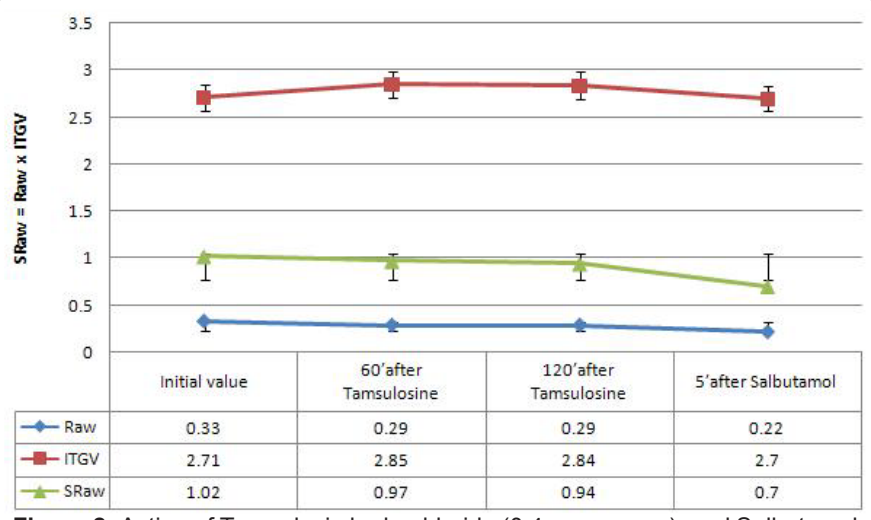

Figure 2: Action of Tamsulosin hydrochloride ( $0.4 \mathrm{mg}$ - per os), and Salbutamol (2 inh. X $0.2 \mathrm{mg}$ ); in Raw, ITGV, and SRaw in persons with middle reactibility $(n=14 ; X \pm S E M)$.

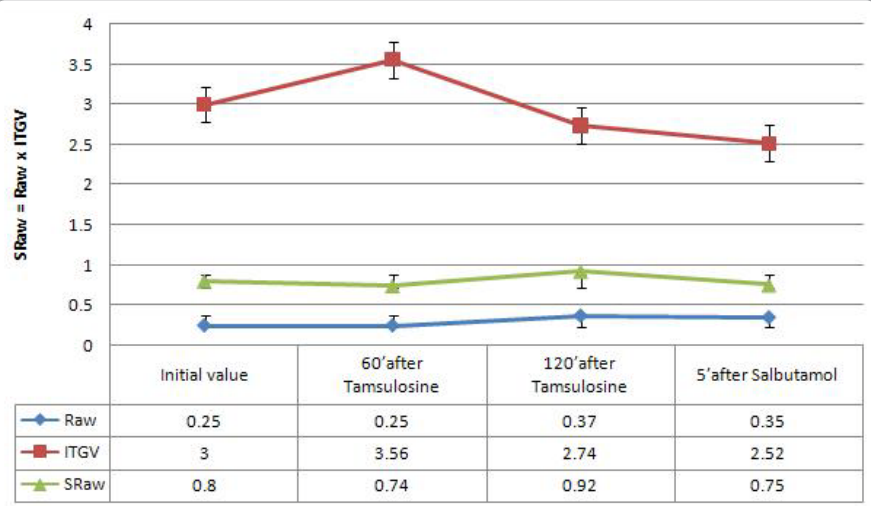

Figure 3: Action of Tamsulosin hydrochloride ( $0.4 \mathrm{mg}$ - per os), and Salbutamol (2 inh. $\times 0.2 \mathrm{mg}$ ); in Raw, ITGV, and SRaw in persons with severe reactibility $(\mathrm{n}=11 ; \mathrm{X} \pm \mathrm{SEM})$.

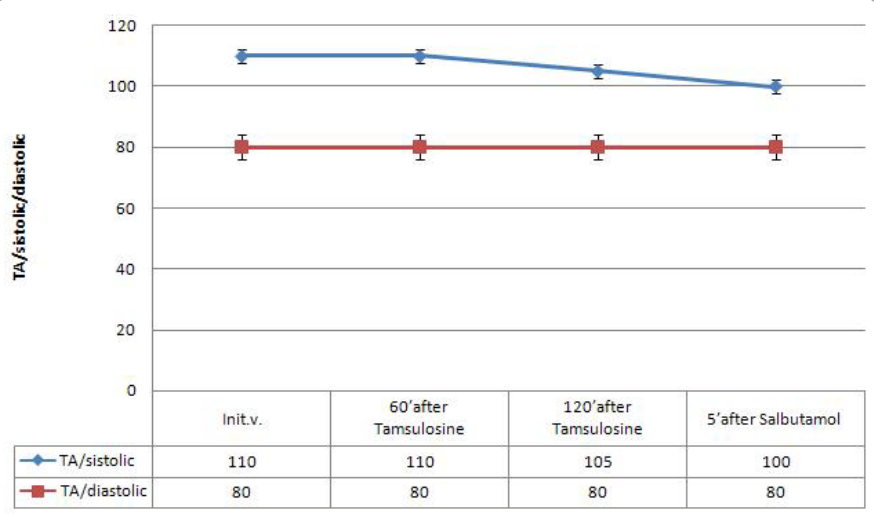

Figure 4: Action of Tamsulosin hydrochloride $(0.4 \mathrm{mg}$ - per os), and Salbutamo (2 inh. $x 0.2 \mathrm{mg}$ ); in arterial pressure (TA/systolic/diastolic); $(n=25 ; \mathrm{X} \pm \mathrm{SEM}$ ).

\section{Discussion}

Regulating of the airways tonus and pharmacology of bronchoconstrictor phenomenon are not quiet known. A huge number of studies, by which regulating of the airways function and their mechanism were studied, indicates the considerable role of relaxing influence of the beta adrenergic receptor and constrictor actions of alpha adrenergic receptor and interaction of neurohumoral factors in this regulation. Existing of these receptors and their role in healthy and ill people from bronchial asthma and chronic obstructive bronchitis is yet discussable.

A fact is that Tamsulosin caused no reaction of alpha ${ }_{1 \mathrm{~A}}$ and alpha $_{1 \mathrm{~B}}$ adrenergic receptors in the permeability of airways with reversible changes of the lung function. Despite our results, some other researchers found alpha $a_{1}$-adrenergic response in airways of patients with bronchial asthma. Worthy to mention here is Lindgren et al. [14] which have demonstrated the inhibition of bronchoconstriction with clonidine, an alpha ${ }_{2}$ adrenergic blocker.

Results of this work shows that blockage of alpha ${ }_{1 \mathrm{~A}}$ and alpha $\mathrm{AB}_{\mathrm{B}}$ adrenergic receptor with Tamsulosin hydrochloride ( $0.4 \mathrm{mg}$ per os) does not change the bronchomotor tonus in patients with increased bronchial hyper-reactibility $(\mathrm{p}>0.1)$. Meantime, agonists of beta ${ }_{2}$ adrenergic receptor (salbutamol) are very effective in removal of increased bronchomotor tonus $(\mathrm{p}<0.01)$. Our earlier results also shows that administration of phentolamine $(10 \mathrm{mg}$, inhalatory and intravenous ways) has not manifested any difference in the performance of functional tests $(\mathrm{p}>0.1)$ [15].

In favor of our research conclusions are also some other authors. Author Shiner and Molho [16] during the research of the effect of the phentolamine in patients with bronchial asthma has not registered any changes of lung functional tests parameters $\left(\mathrm{FEV}_{1}, \mathrm{GAV} / \mathrm{WL} ; \mathrm{V}_{25}\right.$ and $\mathrm{VERV}_{2}$ ) by ascertaining that the increased activity of alpha adrenergic receptor is not the central mechanism in causing of the asthma disease and by emphasizing the dominant role of beta ${ }_{2}$ adrenergic receptor agonists.

Similar results were gained by author Walden et al. [13], which has presented that the blockage of alpha ${ }_{1}$ adrenergic receptor has no significant impact to the reaction of the smooth musculature of airways to histamine. Although in some of patients with asthma are registered improvements of lung functional tests $\left(\mathrm{FEV}_{1}\right)$ but without any significant impact.

Nonetheless, some authors have concluded that asthmatic patients included in the research have manifested heterogenic response to phentolamine by categorizing these patients with positive reaction, patients with negative reaction and patients without reaction to phentolamine. This author assumes that this different reaction to phentolamine is as a result of the different relation of the activity of beta adrenergic receptor, alpha adrenergic and cholinergic receptor at the bronchial tree [17].

Role of the alpha blockers in the airways tonus should not be totally eliminated due to the fact that some authors have concluded that systemic administration of phentolamine causes the increase of the incidence, rate and amplitude of respiratory movements of sheep's fetus in utero during hypoxia. This proves regarding relation of phentolamine in the central mechanisms of breathing, also [17].

In favor of the facts related to the non-significant role of alpha blockers in airways are also conclusions of some of the authors which presents that alpha ${ }_{1}$ blockers does not cause the myorelaxant effect following the induction of bronchoconstriction from the inhalatory therapy with mehacholine and histamine in the experiment with apes. Isoprenaline has manifested direct myorelaxant effect following the induction of bronchoconstriction with aerosol therapy with methacholine and histamine. Meantime, atropine has manifested the partial bronchodilator effect only after inhalation of methacholine yet not after the inhalatory therapy with histamine [18]. 
A question rises whether constriction of smooth respiratory musculature is caused by two sub-types of alpha adrenergic receptors $\left(\right.$ alpha $_{1 \mathrm{~A}}$ and alpha $\left._{1 \mathrm{~B}}\right)$ ? Regarding this, there are neither earlier reports by which to prove two sub-types of alpha adrenergic receptors in the airways musculature nor reports over effects of clonidine in the receptors of smooth musculature [19]. Previous researches have not demonstrated any of the alpha ${ }_{2}$ adrenergic receptor in the respiratory epithelial surface [19]. Inhibitory effect of the clonidine in bronchoconstriction might be induced with straight bronchodilation, or through inhibition of the vagal reflex, or with the inhibition of the release of histamine as an inhibition caused by an antigen [9].

A number of authors have proved that in the group of asthmatics inhaled phenylephrine (agonist of alpha-adrenergic receptor) does not cause significant effect in the airways resistance [10].

These results suggest that action of Tamsulosin hydrochloride depends directly on the presence and structural extension of alpha adrenergic receptor, respectively two sub-types of these receptors, alpha $_{1 \mathrm{~A}}$ and alpha ${ }_{1 \mathrm{~B}}$-adrenergic receptor. Therefore, further researches of the configuration and sub-types of these receptors would assist in clearer defining of the role of these receptors in the mechanism of asthma and persons with increased bronchial hyper-reactibility.

\section{Conclusion}

Based on gained results, it can be concluded as follows:

- Application of Tamsulosin hydrochloride-blocker of receptor (alpha $_{1 \mathrm{~A}}$ and alpha $_{1 \mathrm{~B}}$-adrenergic) applied with per os way in patients with increased bronchial hyper-reactibility, does not cause significant decrease of specific resistance (SRaw) of airways $(\mathrm{p}>0.1)$.

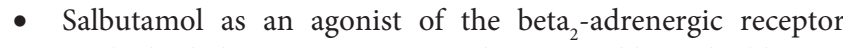
applied inhalatory in patients with increased bronchial hyperreactibility causes a significant decrease of specific resistance (SRaw) of airways $(\mathrm{p}<0.01)$.

This suggests that the activity of alpha ${ }_{1 \mathrm{~A}}$ and alpha ${ }_{1 \mathrm{~B}}$ adrenergic receptor in the smooth bronchial musculature is not a primary mechanism which will cause reaction in patients with increased bronchial reactibility. There is a possibility that sub-types of alpha ${ }_{1 \mathrm{~A}}$ and alfa $_{2 \mathrm{~B}}$ adrenergic receptors persist, yet in insufficient way to react significantly with antagonist alpha-adrenergic substances.

\section{References}

1. Dergacheva O, Griffioen KJ, Neff RA, Mendelowitz D (2010) Respiratory modulation of premotor cardiac vagal neurons in the brainstem. Respir Physiol Neurobiol 174: 102-110.

2. Gilbert IA, Lenner KA, McFadden ER Jr (1988) Sympathoadrenal response to repetitive exercise in normal and asthmatic subjects. J Appl Physiol 64: 26672674.

3. Mathé AA, Aström A, Persson NA (1971) Some bronchoconstricting and bronchodilating responses of the isolated human bronchi: evidence for the existence of -adrenereceptors. J Pharm Pharmacol 23: 905-910.

4. Lux R, Awa W, Walter U (2009) An interdisciplinary analysis of sex and gender in relation to the pathogenesis of bronchial asthma. Respir Med 103: 637-649.

5. Szentivanyi A (1968) The beta adrenergic theory of the atopic abnormality in bronchial asthma. J Allergy 42.

6. Gross GN, Souhrada FJ, Farr RS (1974) The longterm treatment of an asthmatic patient using phentolamine. Chest 66: 397-401.
7. Black JL, Temple DM, Anderson SD (1978) Long-term trial of an alpha adrenoceptor blocking drug (indoramine) in asthma. A preliminary report Scand J Dis 59: 307-312.

8. Rosenthal RR, Kondarskky DW, Rosenberg GL, Norman PS (1976) The role of alpha-adrenergic receptors in allergic asthma. J Allerg Clin Immunol 57: 223.

9. Andersson RG, Fügner A, Lindgren BR, Muacevic G (1986) Inhibitory effects of clonidine on broncospasm induces in vagal stimulation or antigen challenge. Eur J Pharmacol 123: 181-185.

10. Snashall PD, Boother FA, Sterling GM (1978) The effect of alpha-adrenoreceptor stimulation on the airways of normal and asthmatic man. Clin Sci Mol Med 54 283-289.

11. Krop M, Ozumel ZG, Chai W, de Vires R, Fekkes D, et al. (2010) Mast cell degranulation mediates bronchoconstriction via serotonin and not via renin release. Eur J Pharmacol 640: 185-189.

12. Barnes PJ (1989) Airway receptors. Postgrad Med J 65: 532-542.

13. Walden SM, Bleecker ER, Chahal K, Britt EJ, Mason P, et al. (1984) Effect of alpha-adrenergic blockade on exercise-induced asthma and conditioned cold air. Am Rev Respir Dis 130: 357-62.

14. Lindgren BR, Ekström T, Andersson RG (1986) The effect of inhaled clonidine in patients with asthma. Am Rev Respir Dis 134: 266-269.

15. Islami H, Krasniqi S, Ahmetaj H, Haliti N, Kurtishi I, et al. (2011) Phentolamine Action in Permeability of Airways at Patients with Bronchial Asthma. Med Arh 65: 4-8.

16. Shiner RJ, Molho MI (1983) Comparison between an alpha-adrenergic antagonist and a beta 2-adrenergic agonist in bronchial asthma. Chest 83: $602-$ 606.

17. Giussani DA, Moore PJ, Bennet L, Spencer JA, Hanson MA (1995) Alpha 1 and alpha 2-adrenoreceptor actions of phentolamine and prazosin on breathing movements in fetal sheep in utero. J Physiol 486: 249-255.

18. Mue S, Ohmi T, Suzuki S, Tamura G, Hida W, et al. (1983) The Effect of adrenergic and cholinergic on methacholine- and histamine-induced bronchoconstriction in monkeys. Tohoku J Exp Med 140: 109-119.

19. Leff AR, Munoz NM (1981) Evidence for two subtypes of alpha adrenergic receptors in canine airway smooth muscle. J Pharmacol Exp Ther 217: 530535. 